\title{
Exploration and Practice on Application of "Double- tutor System" Team Construction in Graduate Education
}

\author{
Wanchun Zhao \\ College of Petroleum Engineering \\ Northeast Petroleum University \\ Daqing, China \\ Shibin Li \\ College of Petroleum Engineering \\ Northeast Petroleum University \\ Daqing, China
}

\author{
Jihong Zhang \\ College of Petroleum Engineering \\ Northeast Petroleum University \\ Daqing, China
}

Tingting Wang*

School of Electrical Engineering \& Information

Northeast Petroleum University

Daqing, China

*Corresponding author

\begin{abstract}
For a long time, "theory" training model of graduate education in closed condition lacks of practice and innovation ability, resulting in the graduates cannot get into character of enterprise, and seriously separate with the demand of society and enterprise. Combined with training mechanism of graduate majored in oil and gas well engineering major, the paper puts forward the construction program of "double-tutor" teachers team. Through two years of practice, the graduates' theory knowledge and practical ability has been greatly improved, and has received the good effect.
\end{abstract}

Keywords-double-tutor; oil and gas well engineering; training model; team construction

\section{INTRODUCTION}

Graduate education, as the highest level of education structure in our country, has the highest status in the whole chain, the graduate student's innovation ability reflect and guarantee the important of innovation in our country. However, for a long time, graduate education in closed condition lacks of practice and innovation ability, resulting in the graduates cannot get into character of enterprise, and seriously separate with the demand of society and enterprise. In consequence, reforming and improving the cultivation of talents, especially talents compound high-level theoretical knowledge with work practice, is the inevitable choice of higher education especially graduate education when meeting the challenge of knowledge economy, this not only put forward new and higher requirements for our country's higher education, but also give a new connotation of higher education and scientific research, combined with productive labor.

However, the tutor of graduate student training is one of the most important factors in the growing of graduate students. In order to cultivate talents compound theory with practice, there will be a lack of knowledge structure in some degree if we just rely on mechanism of single teacher training, and the quality of students couldn't be guarantee. For this reason, many domestic high schools carry on discussion and practice from multiple levels, for example, strengthen the construction of disciplines, search different model of teaching or tutorial system[1]. Shanghai Jiao Tong University and Baoshan iron and steel Co. LTD. have signed a contract to promote graduate student training mode" Double Tutorial System"[2], expand the project size of joint training master and doctor graduate student, with organic combination of scientific research innovation and personnel training. Cooperation in building laboratory carry out field cluster development and other application fields have instead scientific research projects as the carrier initially. On the training mode, "EVI" mode will be used to let more excellent professional talents "direct to" enterprise, and students can participate in the enterprise's research in advance; Doctoral student of Shandong University adopts a double tutorial system[3]. It requires that one of the two tutors must be school staff, the other one could be outsider (including overseas), or school staff of different discipline (stretch over two disciplines). Responsibility of outside tutor is: Assist inside tutor to develop training plan and guide the graduate students; Provide corresponding scientific research conditions and funds; Participate in guiding master-degree thesis; Participate in master-degree opening report prepared dissertation and dissertation defense; Opening courses or seminars for graduates in relevant area.

Graduate student training mode” Double Tutorial System” has been generated under this demand of enterprise and society, it's a cultivation mechanism consist of theoretical and academic teachers from colleges and universities, and senior technical personnel with training graduate students engineering practice ability and technology experts from industry. "Double Tutorial System” could recover the lack of knowledge structure and scope with single teacher cultivation. For this purpose, this paper put forward the construction scheme of" Double Tutorial System" considering the current cultivate situation of oil and gas well engineering in our school, and the scientific research 
institutes and production practice unit of oilfield enterprises, through the operation of "Double Tutorial System", cultivate theory and technology has been greatly improved. A good effect has been achieved.

\section{PRESENT SITUATION AND THE ANALYSIS OF THE PROFESSIONAL GRADUATE EDUCATION}

Graduates of oil and gas well engineering relying on the first level discipline of oil and gas in our school, the number of recruit graduates has overall 45 person/year, in recent years, with the increasing number of college graduates, enrollment also shows a trend of rising year by year. Table 1 shows the enrollment of oil and gas well engineering.

TABLE I. THE ENROLLMENT OF OIL AND GAS WELL ENGINEERING IN RECENT YEARS

\begin{tabular}{|c|c|c|c|c|}
\hline Year of Enrollment & $\mathbf{2 0 0 9}$ & $\mathbf{2 0 1 0}$ & $\mathbf{2 0 1 1}$ & $\mathbf{2 0 1 2}$ \\
\hline $\begin{array}{c}\text { Professional Degree } \\
\text { Enrollment }\end{array}$ & 10 & 15 & 20 & 25 \\
\hline $\begin{array}{c}\text { Academic Degree } \\
\text { Enrollment }\end{array}$ & 30 & 30 & 35 & 35 \\
\hline
\end{tabular}

Major cultivate directions of graduate are: Oil and gas well engineering mechanics 、 Oil and gas well engineering mechanics of liquids、Oil and gas well work liquefaction、 Theory and design reviews price of oil and gas well technology、Measurement and process control of oil and gas well engineering and other aspects of basic research. For many years, graduates of the oil and gas well engineering have a lot of disadvantage in technology innovation due to the impact of" Attaches great importance to the theory"” Ignore the skills training”, graduates engaged in theoretical study and go on further study after graduation takes up a lot of the proportion, Table 2.

TABLE II. ASSIGNMENT TABLE OF OIL AND GAS WELL ENGINEERING GRADUATES

\begin{tabular}{|c|c|c|c|}
\hline Year of graduation & $\mathbf{2 0 0 9}$ & $\mathbf{2 0 1 0}$ & $\mathbf{2 0 1 1}$ \\
\hline $\begin{array}{c}\text { Number of } \\
\text { graduation }\end{array}$ & 28 & 32 & 26 \\
\hline $\begin{array}{c}\text { Number of } \\
\text { theoretical }\end{array}$ & 16 & 21 & 14 \\
\hline $\begin{array}{c}\text { Occupy the } \\
\text { proportion (\%) }\end{array}$ & 57.14 & 65.63 & 53.85 \\
\hline
\end{tabular}

At the same time, graduates entered enterprises couldn't participate in the production practice of enterprise and society directly, most of them need 6 months skill training. Even worse, some graduates get unemployed because they couldn't meet the requirements of enterprises, this lead a huge waste of these professional graduate student resources.

Unsounded cultivation of innovative talents has become a bottleneck which constraint graduates into the enterprise and society. A single training mode of traditional elite education is difficult to adapt to the requirement of the mass education, too much emphasis on imparting theoretical knowledge and ignore the practice teaching may lead to the separation of education and social needs, study and practical application, students lack of practical ability is also one of the reasons that cause the difficulty of employment. So, Double Tutorial System is a necessary development route.

\section{CONSTRUCtion SCHEME OF DOUble Tutorial System}

Our school rely on "Oil and gas drilling engineering technology research and development institution "set by education department, employed enterprise senior technicians and technical experts as technical consultant and visiting experts of the institution. According to the whole scheme of talent training, optimize theory teaching course system, strength the practice teaching course system, increase the establish of innovation and entrepreneurship courses, guide students join in related research work and product research, so reach the cultivate goal that strengthen the student practical ability and consciousness of innovation. The main construction scheme is embodied in the several aspects:

(1) The construction of tutors, encouraging local young teachers to participate in the oilfield production and actual technical problems research, conducting technical research by combining the technical problems of oilfield enterprises, On the one hand, enhance the teacher experience solving actual work, on the other hand, broaden the horizon of young teachers This plays a guiding role for the following graduate training.

(2) According to "Oil and gas drilling engineering technology research and development institution", import experts and scholars with 3-5 years of related technical field of work check according to well-paid or payment policy.

(3) Employed oilfield enterprise talents who have the teacher qualification as local tutor and leader of development. By the cooperation with Hei Longjiang oil and gas drilling research and development center lab, oil and gas well engineering employ senior technical guide teachers account for forty percent of the number of this professional school teachers.

(4) Achieving schools and enterprises jointly postgraduate training program, on the one hand ,meet the requirement of school tutor that to bring up the graduate students on basic theory , and meet the requirement of enterprises mentor that to bring up the graduate students on engineering practice innovation capability, on the other hand. To broaden the scope of mentor, mentor's guidance is not only limited to research, its range may involve course paper and many other scientific and social practice.

(5) Responsibility is implemented on dual mentor when graduate design is done. In the development of oil and gas wells graduate design program, drawing up graduation design issues, make sure issue is not unrealistic! oil companies' tutors regularly come to the school to do technical exchanges, and leave technical issues. Dual Tutorial Mode of Training cooperation allow students to participate in business development in advance, make scientific research achievements transformed into productive forces as soon as possible.

\section{PROGRAM IMPLEMENTATION AND EFFECT ANALYSIS}

(1) Caused by external personnel policy, in 2012, we introduced 3 postdoctoral who have five years of experience and they have been involved in guiding 2012 graduate work. 
TABLE III. SCHEDULE OF INTRODUCE TALENTS IN OIL AND GAS DRILLING R\&D CENTER IN 2012

\begin{tabular}{|c|c|c|c|}
\hline Name & $\begin{array}{c}\text { Education } \\
\text { background }\end{array}$ & $\begin{array}{l}\text { Years of } \\
\text { working }\end{array}$ & Former work unit \\
\hline Zhao & Doctor & 5 & $\begin{array}{l}\text { Yumen oilfield co. } \\
\text { LTD }\end{array}$ \\
\hline $\mathbf{L i}$ & Doctor & 3 & $\begin{array}{lll}\text { Daqing oilfield co. } \\
\text { LTD }\end{array}$ \\
\hline Wei & Doctor & 3 & $\begin{array}{l}\text { Daqing oilfield co. } \\
\text { LTD }\end{array}$ \\
\hline
\end{tabular}

(2) 2012, we hire oil companies experts to do academic reports twice, and invite them to participate in the development of oil and gas well engineering graduate training program and training program for 2012.

TABLE IV. OIL AND GAS DRILLING R\&D CENTER OF EXPERT LECTURES IN 2012

\begin{tabular}{|l|l|}
\hline \multicolumn{1}{|c|}{ Lecture topic } & \multicolumn{1}{|c|}{ Former work unit } \\
\hline $\begin{array}{l}\text { The advanced technology of modern } \\
\text { drilling and analysis for the technology } \\
\text { difficult problems }\end{array}$ & $\begin{array}{l}\text { Daqing drilling engineering } \\
\text { company }\end{array}$ \\
\hline $\begin{array}{l}\text { To optimize the Hide well type and } \\
\text { Trajectory design for Complex well }\end{array}$ & Changqing oilfield co. LTD \\
\hline
\end{tabular}

(3) Oil and gas wells engineering profession graduates employment survey of 2012, we found that graduate employment rate increased by $32 \%$.

\section{CONCLUSION}

By the construction of double team mentor and new teacher hiring tutors in teaching practice, Petroleum Engineering school of Northeast Petroleum University(Oil and Gas Well Engineering Major) graduate education fond the teaching system that adapt to the characteristics of profession, and achieved good results, mainly in the following aspects:

(1) Double tutors graduate students in favor of multidisciplinary academic guidance, broaden their horizons, by the way practice on oil field ,students directly involved in the actual work or research projects outside the unit's supervisor, change the phenomenon of graduate education theory and practice disjointed.

(2) By established long-term cooperative relationship with oil and gas drilling \& development center, we'll regularly introduce a number of excellent technical instructors. More clear and responsible for training and orientation wells engineering graduate, business mentor through field experience to teach and guide students to increase understanding and awareness of engineering deeper on.

(3) Student-site training, and cooperation with various field units, solves the employment problem of some graduates. Students can select talent for employment and a certain intention by internships oilfield units at a time, and that play a role to alleviate the current academic employment issues.

\section{ACKNOWLEDGEMENTS}

This research was financially supported by Teaching reform project in Heilongjiang province department of education (JG2013010160),Graduate education teaching reform project in northeast petroleum

(JGXM_NEPU_201302),Teaching
Heilongjiang province department of education (JG2014010636) .

\section{REFERENCES}

[1] Yang Guowu,Li Jianping,Lu Xiaojun. Exploration and research in the University of electronic science and technology about doctoral double tutorial at home and abroad[J]. Computer education ,2006:146-148.

[2] Xiao Guofang,Wu Song, Peng Shulian.The new pattern of graduate student training university-industry cooperation -"The traffic university Baosteel” The characteristics of graduate student training mode and thinking[J].China higher education research, 2006:23-25.

[3] Zhang Xiaojing. Graduate education in shandong university adopts a double tutorial system.2006:34-37. 
